\title{
Effect of stocking rate and animal genotype on dry matter intake, milk production, body weight, and body condition score in spring-calving, grass-fed dairy cows
}

\author{
E. L. Coffey, ${ }^{*} \dagger^{1}$ L. Delaby, $\ddagger$ S. Fitzgerald, ${ }^{*}$ N. Galvin, ${ }^{*}$ K. M. Pierce, $†$ and B. Horan* \\ *Animal and Grassland Research and Innovation Centre, Teagasc Moorepark, Fermoy, Co. Cork, Ireland \\ †School of Agriculture, Food Science and Veterinary Medicine, University College Dublin, Belfield, Dublin 4, Ireland \\ †INRA, AgroCampus Ouest, UMR 1348, Physiologie, Environnement et Génétique pour l'Animal et les Systèmes d'Elevage, \\ F-35590 Saint-Gilles, France
}

\section{ABSTRACT}

The objective of the experiment was to quantify the effect of stocking rate (SR) and animal genotype on milk production, dry matter intake (DMI), energy balance, and production efficiency across 2 consecutive grazing seasons (2014 and 2015). A total of 753 records from 177 dairy cows were available for analysis: 68 Holstein-Friesian and 71 Jersey $\times$ Holstein-Friesian (JxHF) cows each year of the experiment under a pasture-based seasonal production system. Animals within each breed group were randomly allocated to 1 of 3 whole-farm SR treatments defined in terms of body weight per hectare ( $\mathrm{kg}$ of body weight/ha): low $(1,200$ $\mathrm{kg}$ of body weight/ha), medium $(1,400 \mathrm{~kg}$ of body weight/ha), and high (1,600 $\mathrm{kg}$ of body weight/ha), and animals remained in the same SR treatments for the duration of the experiment. Individual animal DMI was estimated 3 times per year at grass using the nalkane technique: March (spring), June (summer), and September (autumn), corresponding to 45,111 , and $209 \mathrm{~d}$ in milk, respectively. The effects of SR, animal genotype, season, and their interactions were analyzed using mixed models. Milk production, body weight, and production efficiency per cow decreased significantly as SR increased due to reduced herbage availability per cow and increased grazing severity. As a percentage of body weight, JxHF cows had higher feed conversion efficiency, higher DMI and milk solids (i.e., $\mathrm{kg}$ of fat + $\mathrm{kg}$ of protein) production, and also required less energy intake to produce $1 \mathrm{~kg}$ of milk solids. The increased production efficiency of JxHF cows at a similar body weight per hectare in the current analysis suggests that factors other than individual cow body weight contribute to the improved efficiency within intensive grazing

Received February 1, 2017.

Accepted May 11, 2017.

${ }^{1}$ Corresponding author: emmalouise.coffey@teagasc.ie systems. The results highlight the superior productive efficiency of high genetic potential crossbred dairy cows within intensive pasture-based milk production systems at higher SR where feed availability is restricted.

Key words: stocking rate, crossbreeding, dry matter intake, production efficiency

\section{INTRODUCTION}

High-productivity grazing systems depend on achieving the correct balance between the competing objectives of managing swards to achieve high pasture growth, feed quality, and utilization while maintaining relatively high levels of individual cow DMI. Within such systems, grazed grass is the cheapest feed source, providing a comparatively inexpensive and high-quality nutrient supply (Shalloo et al., 2004; Finneran et al., 2010). Consequently, maintaining a high proportion of overall milk production from grazed grass has a pervasive antagonistic effect on both direct and overhead milk production costs within such systems (Dillon et al., 2008; Ramsbottom et al., 2015). Moreover, although productivity within such systems is frequently measured in terms of milk solids (MS; fat plus protein) production per hectare, such analysis belies the significant effects of pasture productivity and utilization, and feed supplementation on farm system performance (Holmes et al., 2002). Within intensive predominantly grazing systems, pasture production and utilization limit milk productivity, and consequently, more recent studies have defined productive efficiency at a grazing systems level in terms of milk production per unit of pasture eaten and per unit of pasture used (Prendiville et al., 2009; Coleman et al., 2010; McCarthy et al., 2012).

Improving the efficiency of forage conversion to milk by grazing dairy cows has been extensively studied within the literature, and significant effects of overall grazing system design, animal nutrition, and animal 
breed and genetic merit have been widely reported (Tozer et al., 2004; Macdonald et al., 2008a; Prendiville et al., 2009; McCarthy et al., 2013). Foremost among these factors, the inverse relationship between stocking rate $(\mathbf{S R})$ and individual animal productivity is now well understood (for review, see McCarthy et al., 2011). An overall medium SR provides an appropriate trade off to realize high pasture utilization and efficient conversion of nutrients to product in such systems (Tozer et al., 2004).

As pasture productivity limits have constrained the performance of intensive grazing systems, increasing emphasis has been placed on the selection of dairy cows capable of increased feed conversion efficiency (FCE) within intensified systems. The inclusion of gross feed efficiency measures within breeding objectives for grazing systems has received much attention albeit with variable success (Berry and Crowley, 2013; Pryce et al., 2015). Individual cow BW has been widely used as a predictor of $\mathrm{FCE}$ as the lower maintenance requirements of lighter cows was considered desirable ceteris paribus (Stakelum and Connolly, 1987; Veerkamp, 1998; Horan et al., 2006). More recently, considerable evidence has suggested that, in comparison with Holstein-Friesian $(\mathbf{H F})$ cows of similar overall genetic merit, Jersey $\times$ Holstein-Friesian crossbred ( JxHF) cows characterized by lower BW, increased intake per unit BW, and greater efficiency of utilization of feed for milk and tissue production, may be more suited to intensive grazing systems on an individual cow basis (Goddard and Grainger, 2004; Prendiville et al., 2009; Vance et al., 2012; Beecher et al., 2014). Notwithstanding these reported benefits, there is a paucity of research evaluating the potential advantages of JxHF cows with enhanced intake capacity and ability to consume roughage within pasture-based systems.

Identifying the appropriate SR is the principal decision to managing a sustainable pasture-based system. Stocking rate has implications for pasture production and utilization as well as individual cow performance among other factors that influence the pasture-livestock relationship (McCarthy et al., 2015). Although the results of animal genotype (BR) comparison experiments are unequivocal in observing improved grazing and milk production efficiency among JxHF cows, it is also widely acknowledged that comparing animals of differing BW (and associated maintenance requirements) on an individual animal basis confers a systemic advantage to the smaller animal (McCarthy et al., 2013; Dong et al., 2015). Consequently, it is unclear if the superior FCE of JxHF animals is retained within intensified grazing systems where SR may be defined in terms of BW per hectare.
The objective of the present experiment was to investigate the effects of SR and BR on DMI, milk production, and FCE within pasture-based systems wherein $\mathrm{SR}$ is defined in terms of kilograms of BW per hectare across 2 consecutive grazing seasons.

\section{MATERIALS AND METHODS}

The present experiment was undertaken at the Animal \& Grassland Research and Innovation Center, Teagasc Moorepark, Ireland $\left(50^{\circ} 7 \mathrm{~N} ; 8^{\circ} 16 \mathrm{~W}\right)$, over a 2-yr period (2014 and 2015). It formed part of a larger systems experiment designed to examine the biological and economic effect of alternative SR and BR combinations. The on-site swards used were predominantly perennial ryegrass (Lolium perenne L.) and had been reseeded over the previous $10 \mathrm{yr}$.

\section{Experimental Design, Treatments, and Animals}

The experiment was a randomized block design with a $3 \times 2$ factorial arrangement of treatments. The 6 experimental treatments consisted of 3 SR: low SR (LSR; $1,200 \mathrm{~kg}$ of BW/ha), medium SR (MSR; $1,400 \mathrm{~kg}$ of BW/ha), and high SR (HSR; 1,600 kg of BW/ha) and 2 BR: HF and JxHF. Treatment farmlets were 9.17, 7.87, and 7.01 ha in size for each BR in LSR, MSR, and HSR treatments, respectively. The LSR treatment group was designed to allow individual cows achieve high DMI and milk production while the MSR and HSR measured potential milk production and herbage utilization per hectare. In total, 177 spring-calving dairy cows were used as part of the experiment; $68 \mathrm{HF}$ and $71 \mathrm{JxHF}$ were used in each year of the experiment (2014 and 2015; Table 1). The replacement rate of the experimental herd was approximately $27 \%$ across the 2-yr DMI measurement period. Cows were culled as a result of failure to establish or maintain pregnancy, lameness, and mastitis. The crossbred cows were JxHF $50 / 50 \mathrm{~F}_{1}$ and were produced from HF dairy cows sired by Jersey bulls. The average economic breeding index (EBI), milk, fertility, calving, beef, maintenance, management, and health sub-indices of the HF cows were $€ 205,64,103,33,-12,16,2$, and -1 , respectively, whereas the average EBI, milk, fertility, calving, beef, maintenance, management, and health sub-indices of the JxHF cows were $€ 198,68,89,30,-23,32,3$, and -1 , respectively. The average EBI of the cows during the experiment (ICBF, 2015) ranked them in the top $1 \%$ of the national dairy herd during the same period. Cows within each BR group were randomly assigned precalving (based on expected calving date, parity, and $\mathrm{EBI})$ to 1 of the $3 \mathrm{SR}$ treatments. Cows were retained 
Table 1. Number of cows and lactation records within each stocking rate ${ }^{1}$ and breed group ${ }^{2}$ for each year of the experiment

\begin{tabular}{|c|c|c|c|c|c|c|}
\hline \multirow[b]{2}{*}{ Item } & \multicolumn{2}{|c|}{ Low } & \multicolumn{2}{|c|}{ Medium } & \multicolumn{2}{|c|}{ High } \\
\hline & $\mathrm{HF}$ & JxHF & $\mathrm{HF}$ & $\mathrm{JxHF}$ & $\mathrm{HF}$ & $\mathrm{JxHF}$ \\
\hline $\begin{array}{l}\text { Stocking rate } \\
\mathrm{kg} \text { of } \mathrm{BW} / \mathrm{ha}\end{array}$ & \multicolumn{2}{|c|}{1,200} & \multicolumn{2}{|c|}{1,400} & \multicolumn{2}{|c|}{1,600} \\
\hline Cows/ha & 2.4 & 2.5 & 2.9 & 3.0 & 3.3 & 3.4 \\
\hline Animals (no.) & 22 & 23 & 23 & 24 & 23 & 24 \\
\hline Average parity & 2.30 & 2.20 & 2.26 & 2.15 & 2.27 & 2.18 \\
\hline
\end{tabular}

within their respective SR treatments for the duration of the experiment.

\section{Grazing Management and Feed System}

Cows were turned out to grass by day and night, as they calved, from early February. A rotational stocking system was practiced, and on-off grazing (Kennedy et al., 2009) was used as a management tool to facilitate grazing during periods of inclement weather. Grazing management was accomplished by weekly monitoring of farm grass cover within each SR treatment. Breed groups within each SR were grazed in sub-paddocks adjacent to each other and were managed similarly [i.e., similar target pregrazing yield, postgrazing compressed sward height (postCSH), and residency time in paddocks]. The residency time within each paddock, ranging from 1.5 to $2.5 \mathrm{~d} /$ sub-paddock, was determined by targeting postCSH of 45 to 50,40 to 45 , and 35 to 40 $\mathrm{mm}$ for LSR, MSR, and HSR, respectively, and each group was moved to the next paddock once this target was reached. Weekly grazing management during the first rotation (February 1 to April 1) was based on allocating an equal and increasing proportion of each farmlet to each treatment up to the start of rotation 2. Nitrogen fertilizer application was similar for all SR treatment groups (250 kg of N/ha per yr). Nitrogen was allocated across 3 distinct seasons: spring (January 15 to March 31), summer (April 1 to July 31), and autumn (August 1 to September 15). Spring, summer, and autumn nitrogen application accounted for $60 \mathrm{~kg}$ of N/ha (24\%), $140 \mathrm{~kg}$ of N/ha (56\%), and $50 \mathrm{~kg}$ of $\mathrm{N} /$ ha $(20 \%)$, respectively. All silage was conserved in bales (weighing on average $259 \mathrm{~kg}$ of DM). A sample of herbage was taken before baling for DM determination, and bales were weighed from each paddock to give an estimate of the amount of feed conserved from each paddock. No mechanical topping of the swards took place for the duration of the experiment.

The aim was to feed equal concentrate per hectare regardless of SR. Concentrate supplementation was similar for all SR treatment groups (approximately $1,000 \mathrm{~kg}$ of $\mathrm{DM} / \mathrm{ha}$ ), and therefore, a lower level of supplement was fed per cow at higher SR (LSR: 400 $\mathrm{kg}$ of DM/cow; MSR: $345 \mathrm{~kg}$ of DM/cow; and HSR: $305 \mathrm{~kg}$ of $\mathrm{DM} / \mathrm{cow}$ ) as per the supplementation plan. Increasing SR did not result in increased concentrate supplementation per cow. Concentrate supplementation for all treatments commenced at $4 \mathrm{~kg} / \mathrm{d}$ postcalving and was reduced and removed only when grass supply exceeded animal demand for all treatments (usually in mid-March). Concentrate was reintroduced when grass supply was inadequate. When a feed deficit arose for 1 of the 3 SR treatments, conserved forage produced within that SR treatment was used to supplement feed supply. The ingredient composition of the concentrate feed was barley $25 \%$, corn gluten $26 \%$, beet pulp $35 \%$, soybean meal $11 \%$, and minerals plus vitamins $3 \%$. Mean concentrate quality was $154 \mathrm{~g} / \mathrm{kg}$ of CP, $177 \mathrm{~g} /$ $\mathrm{kg}$ of crude fiber, $105 \mathrm{~g} / \mathrm{kg}$ of ash, and $895 \mathrm{~g} / \mathrm{kg}$ of OM.

\section{Animal Measurements}

Cows were milked twice daily throughout lactation across the $2 \mathrm{yr}$ of the experiment. The milking process was carried out at 0700 and $1530 \mathrm{~h}$ daily. Weekly milk production was derived from individual cow milk yield $(\mathrm{kg})$ recorded at each milking (Dairymaster, Causeway, Co. Kerry, Ireland). Milk fat, protein, and lactose concentrations were determined across successive p.m. and a.m. milkings; samples of milk were analyzed each week using a MilkoScan 203 (Foss Electric, Hillerød, Denmark), and weekly solids-corrected milk (SCM; Tyrrell and Reid, 1965), fat, protein, lactose, and MS yields were calculated. Individual cow BW and BCS were recorded fortnightly. Body weight was recorded upon exit from the milking parlor using an electronic scale (Tru-Test Limited, Auckland, New Zealand). Animal BCS was measured on a 1 to 5 scale $(1=$ thin, $5=$ fat) in increments of 0.25 as outlined by Edmonson et al. (1989). Body condition was scored by 1 individual throughout the experiment. 
Measurements of individual cow DMI were estimated using the n-alkane technique (Mayes et al., 1986) as modified by Dillon and Stakelum (1989). Individual DMI were measured on 3 occasions during the grazing season $(\mathbf{S})$ in 2014 and 2015, corresponding with spring (March; DIM = 45), summer (June; DIM = 111), and autumn (September; DIM = 209). Observations of cow DMI were collected over a range of 15 to 243 DIM. Cows were dosed twice daily after milking with paper bungs containing $500 \mathrm{mg}$ of C32-alkane (n-dotriacontane) over a 12 -d period. On d 7 to 12 , fecal grab samples were collected from each cow. These were subsequently bulked for analysis. Selected herbage samples were also taken to postgrazing height following postCSH observations of the grazing dairy cows. The ratio of herbage C33-alkane (tritriacontane) to dosed C32-alkane was used to estimate DMI.

Measures of milk production efficiency were calculated based on the net energy system (Faverdin et al., 2011), where 1 unité fourragère lait (UFL) of energy is defined as the net energy content of $1 \mathrm{~kg}$ of standard barley for milk production, equivalent to $1,700 \mathrm{kcal}$. The measures of milk production efficiency were total DMI per $100 \mathrm{~kg}$ of $\mathrm{BW}$, MS (kg) per $100 \mathrm{~kg}$ of BW, UFL available for standard (4.0\% fat and $3.1 \%$ protein content) milk production after accounting for maintenance and gestation, and UFL required to produce 1 $\mathrm{kg}$ of milk and MS (g) per UFL intake before and after accounting for maintenance.

\section{Grass Measurements}

Grazing data were collected from all paddocks grazed during the intake measurement periods across the 2 yr. Pregrazing herbage mass $(>35 \mathrm{~mm})$ was determined before grazing on each paddock for each of the 6 farmlets by harvesting a strip $(1.2 \times 10 \mathrm{~m})$ of grass with an Etesia mower (Etesia UK Ltd., Warwick, UK). All mown herbage from each strip was collected and weighed, and a $0.1 \mathrm{~kg}$ (fresh weight) subsample was taken and dried for $16 \mathrm{~h}$ at $90^{\circ} \mathrm{C}$ for $\mathrm{DM}$ determination. Ten compressed sward height (CSH) measurements were recorded before and after harvesting on each cut strip using a folding grass plate meter with a steel plate (Jenquip, Fielding, New Zealand). Sward density was calculated using the measurement below (Delaby and Peyraud, 1998):

sward density $(\mathrm{kg}$ of $\mathrm{DM} / \mathrm{mm}$ per ha $)=$ pasture mass (kg of DM/ha)/(precutting CSH - postcutting CSH).

Pregrazing CSH and postgrazing CSH were determined for each paddock before and after grazing by taking 30 measurements across the diagonal of the paddock. The average paddock pregrazing herbage mass and daily herbage allowance (DHA) above a cutting height of $35 \mathrm{~mm}$ was then calculated using the measurements below:

$$
\begin{aligned}
& \text { pregrazing herbage mass }(\mathrm{kg} \text { of } \mathrm{DM} / \mathrm{ha})= \\
& {[\text { preCSH }(\mathrm{mm})-35 \mathrm{~mm}] \times \text { sward density }} \\
& (\mathrm{kg} \text { of } \mathrm{DM} / \mathrm{mm} \text { per ha }),
\end{aligned}
$$

where average DHA = pregrazing herbage mass, $\mathrm{kg}$ of $\mathrm{DM} /$ ha $\times$ daily grazing area allowance (ha/cow).

\section{Statistical Analysis}

All statistical analysis was carried out using SAS (SAS Institute Inc., 2010). The effect of SR, BR, and S, and their interactions $(\mathrm{SR} \times \mathrm{BR}, \mathrm{SR} \times \mathrm{S}, \mathrm{BR} \times \mathrm{S}$, and $\mathrm{SR} \times \mathrm{BR} \times \mathrm{S})$ on mean daily milk production, $\mathrm{BW}$, BCS, grass DMI, total DMI, and production efficiency during each DMI measurement periods during the $2 \mathrm{yr}$ of the experiment were analyzed using mixed models (PROC MIXED). Year (2014 and 2015), parity (1, 2, $\geq 3$ ), SR (low, medium, and high), BR (HF and JxHF), and S (spring, summer, and autumn) were included as fixed effects, whereas calving day of year and genetic merit (EBI) were included as continuous effects. To take account of multiple measurements for individual cows, cow-year was included as a random effect in the model. The effect of SR, BR, and S, and their interactions $(\mathrm{SR} \times \mathrm{BR}, \mathrm{SR} \times \mathrm{S}, \mathrm{BR} \times \mathrm{S}$, and $\mathrm{SR} \times \mathrm{BR} \times \mathrm{S})$ on grazing characteristics and sward nutritive quality data for the DMI measurement periods were analyzed using mixed models (PROC MIXED). Year, SR, BR, and $\mathrm{S}$ were included as fixed effects in the model.

\section{RESULTS}

\section{Grazing Characteristics and Herbage Allowance}

The effects of SR, BR, and S on grazing characteristics and herbage allowance during the intake measurement periods are presented in Table 2. Stocking rate had a significant effect on grazing characteristics and herbage allowance. Pregrazing herbage mass ( $\mathrm{kg}$ of DM/ha) was similar in MSR and HSR treatments $(1,608$ and $1,697 \mathrm{~kg}$ of $\mathrm{DM} /$ ha, respectively) and greatest $(P=0.006)$ in LSR $(1,879 \mathrm{~kg}$ of $\mathrm{DM} / \mathrm{ha})$. A consistent significant effect was present of SR on postCSH with lower $(P<0.001)$ postCSH for the MSR and HSR treatments (37 and $35 \mathrm{~mm}$, respectively) in comparison with LSR (43 mm). Consequently, DHA was greatest for LSR (20.0 kg of DM/cow), least for HSR (13.3 kg 
of $\mathrm{DM} / \mathrm{cow})$, and intermediate for MSR (14.8 $\mathrm{kg}$ of $\mathrm{DM} /$ cow $)$. Season had a significant effect $(P<0.001)$ on all grazing characteristics with postCSH and DHA greatest $(P<0.001)$ in summer $(41 \mathrm{~mm}$ and $19.8 \mathrm{~kg}$ of $\mathrm{DM} /$ cow, respectively), intermediate in the autumn (40 $\mathrm{mm}$ and $15.7 \mathrm{~kg}$ of $\mathrm{DM} /$ cow, respectively), and least in the spring $(34 \mathrm{~mm}$ and $12.5 \mathrm{~kg}$ of $\mathrm{DM} / \mathrm{cow}$, respectively). Pregrazing herbage mass was greater $(P$ $<0.001)$ in the summer $(2,026 \mathrm{~kg}$ of DM/ha) compared with spring and autumn (1,586 and 1,573 $\mathrm{kg}$ of DM/ha, respectively). Pregrazing herbage height was similar for MSR $(81 \mathrm{~mm})$ and HSR $(85 \mathrm{~mm})$ and greatest $(P<$ 0.001) for LSR (94 mm).

No significant effect was observed of BR or interactions of SR, BR, and S evident on any of the grazing characteristics measured during the experiment.

\section{Sward Nutritive Quality}

The effect of SR, S, and the $\mathrm{SR} \times \mathrm{S}$ interaction on organic matter digestibility (OMD), CP, NDF, ADF, and energy (UFL) content during the intake measurement periods are described in Table 3. No consistent effect was observed of SR on sward nutritive value. Season had a significant effect on all sward quality traits. Neutral detergent fiber and OMD were similar in spring (367 g/ $\mathrm{kg}$ of DM and $85 \%$, respectively) and summer (364 g/ $\mathrm{kg}$ of DM and $86 \%$, respectively), but as OMD decreased $(81 \% ; P=0.002)$ in autumn, NDF increased $(399 \mathrm{~g} / \mathrm{kg}$ of DM; $P<0.001)$. Crude protein was greatest $(P<0.01)$ in spring $(205 \mathrm{~g} / \mathrm{kg})$, compared with 180 and $182 \mathrm{~g} / \mathrm{kg}$ in summer and autumn, respectively. Acid detergent fiber was least $(P<0.001)$ in summer $(195 \mathrm{~g} / \mathrm{kg})$ compared with spring and autumn (218 and $228 \mathrm{~g} / \mathrm{kg}$, respectively). The energy content of the swards grazed during the intake measurement periods was greatest $(P<0.001)$ in the summer $(1.06$ $\mathrm{UFL} / \mathrm{kg}$ of DM), intermediate in the spring (1.04 UFL/ $\mathrm{kg}$ of $\mathrm{DM})$, and least in the autumn (1.01 UFL $/ \mathrm{kg}$ of $\mathrm{DM})$.

\section{Milk Production, BW, and BCS}

The effect of SR, BR, and S on milk production, BW, and BCS during the intake measurement periods are described in Table 4. Stocking rate had a significant effect on all milk production traits. The LSR treatment achieved the greatest $(P<0.001)$ daily milk $(22.0 \mathrm{~kg} /$ cow), fat (1.06 kg/cow), protein $(0.81 \mathrm{~kg} /$ cow $)$, lactose $(1.06 \mathrm{~kg} / \mathrm{cow}), \mathrm{SCM}(23.9 \mathrm{~kg} / \mathrm{cow})$, and MS $(1.88 \mathrm{~kg} /$ cow), whereas performances were similar between MSR (20.8, 0.99, 0.76, 0.99, 22.1, and $1.75 \mathrm{~kg} /$ cow, respectively) and HSR (20.9, 1.00, 0.75, 0.99, 21.9, and 1.74 $\mathrm{kg} / \mathrm{cow}$, respectively). Additionally, SR had a significant effect on BW $(P<0.001)$ with LSR heaviest $(489 \mathrm{~kg})$, HSR lightest (463 kg), and MSR intermediate (479 kg), whereas no significant SR effect was present on BCS. A significant linear effect $(P<0.001)$ of SR on daily milk yield was detected with a decrease of $0.30(\mathrm{SE}=0.19)$ $\mathrm{kg}$ of milk/cow for each additional $100 \mathrm{~kg}$ of BW/ha. Breed had a significant effect on daily milk, fat, and lactose yield. Holstein-Friesian cows produced more milk $(21.9 \mathrm{~kg} /$ cow per day; $P<0.001)$ and lactose $(1.04 \mathrm{~kg} /$ cow per day; $P<0.001)$ but less fat $(0.99 \mathrm{~kg} /$ cow per day; $P<0.001)$ and MS $(1.77 \mathrm{~kg} /$ cow per day; $P=$ $0.087)$ compared with JxHF cows $(21.3,1.02,1.08$, and $1.81 \mathrm{~kg} /$ cow per day, respectively). Jersey $\times$ HolsteinFriesian cows had greater $(P<0.001)$ milk composition than HF cows; fat, protein, and lactose percentages were $5.13,3.80$, and $4.78 \%$ for JxHF, respectively, compared with $4.58,3.60$, and $4.74 \%$, respectively, for $\mathrm{HF}$ cows. Mean BW was $7.3 \%$ greater $(P<0.001)$ for $\mathrm{HF}$ cows (495 kg) than JxHF cows $(459 \mathrm{~kg})$ during the experiment. Season had a significant effect on all milk production traits, BW, and BCS. Greatest $(P<0.001)$ daily milk $(25.2 \mathrm{~kg} / \mathrm{cow})$, fat $(1.18 \mathrm{~kg} / \mathrm{cow})$, protein $(0.86 \mathrm{~kg} / \mathrm{cow})$, lactose $(1.21 \mathrm{~kg} / \mathrm{cow}), \mathrm{SCM}(26.1 \mathrm{~kg} /$ cow), and MS (2.04 kg/cow) was achieved in the spring, and least in the autumn $(16.4,0.86,0.67,0.76,18.8$, and $1.54 \mathrm{~kg} /$ cow, respectively), whereas summer was intermediate $(21.6,1.01,0.79,1.07,22.9$, and $1.75 \mathrm{~kg} /$ cow, respectively). Body weight $(P<0.001)$ and BCS $(P<0.05)$ were also least in the spring $(444 \mathrm{~kg}$ and 2.95 , respectively), intermediate in the summer (473 $\mathrm{kg}$ and 2.97, respectively), and greatest in the autumn (513 kg and 2.98, respectively).

No significant effect was present on the interactions of SR, BR, and S for milk production, BW, and BCS during the experimental period.

\section{Grass DMI, Total DMI, and Energy Intake}

The effect of SR, BR, and S on grass and total DMI and energy intake are presented in Table 5. Stocking rate, $\mathrm{BR}$, and $\mathrm{S}$ had a significant effect $(P<0.001)$ on grass and total DMI. The LSR treatment achieved the greatest $(P<0.001)$ daily grass $(15.3 \mathrm{~kg}$ of DM/ cow) and total (17.0 kg of DM/cow) DMI, whereas daily grass and total DMI were similar between MSR (14.2 and $16.0 \mathrm{~kg}$ of DM/cow, respectively) and HSR (13.9 and $15.6 \mathrm{~kg}$ of DM/cow, respectively). Equally, HF cows achieved a greater $(P<0.001)$ daily grass $(14.8 \mathrm{~kg}$ of $\mathrm{DM} / \mathrm{cow})$ and total $(16.5 \mathrm{~kg}$ of $\mathrm{DM} / \mathrm{cow})$ DMI compared with JxHF cows (14.2 and $15.9 \mathrm{~kg}$ of $\mathrm{DM} /$ cow, respectively). Grass DMI was greatest during summer $(P<0.001 ; 15.6 \mathrm{~kg}$ of $\mathrm{DM} /$ cow per day $)$, intermediate in autumn (15.3 kg of DM/cow per day), and least in spring (13.9 $\mathrm{kg}$ of $\mathrm{DM} / \mathrm{cow}$ per day). To- 
STOCKING RATE AND BREED EFFECTS ON PRODUCTION EFFICIENCY

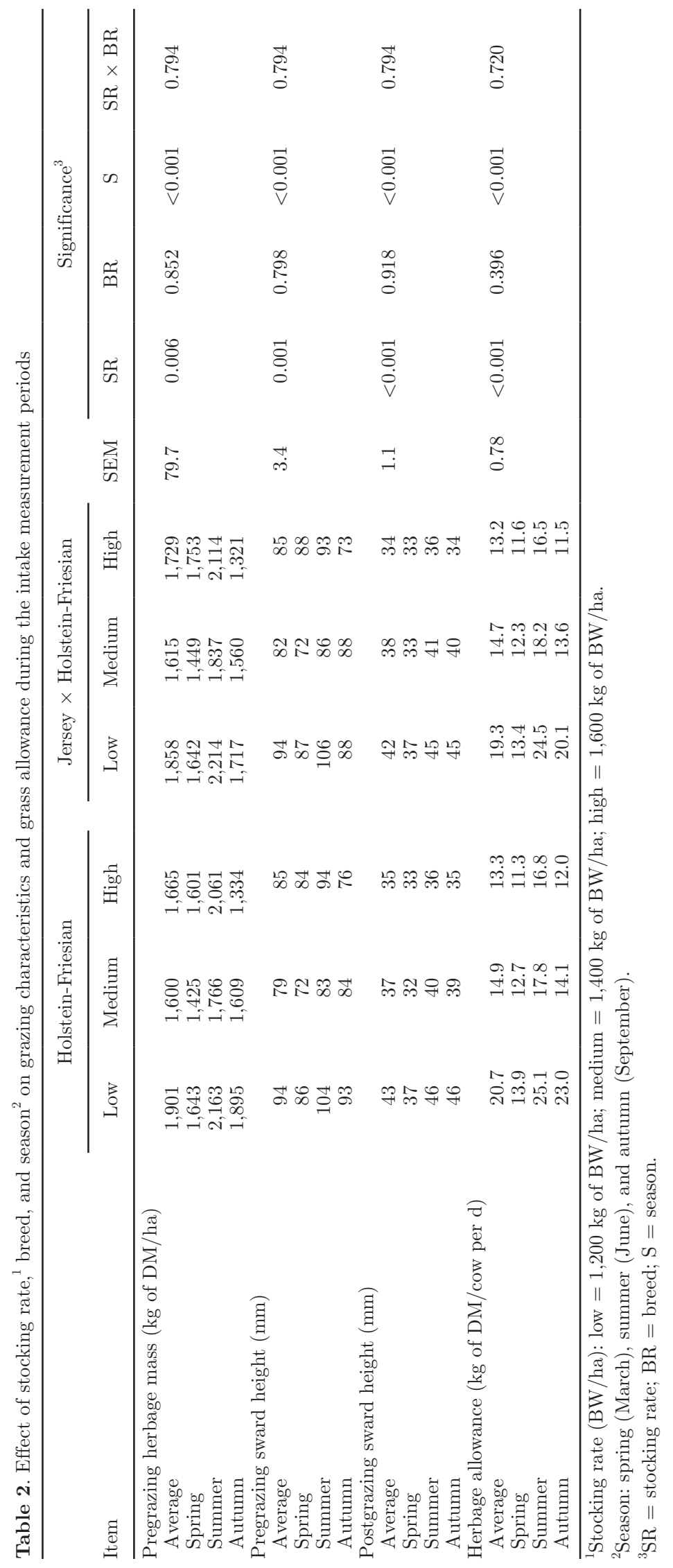


tal DMI differed from grass DMI due to concentrate supplementation in spring and autumn. Owing to the increased requirement for supplementation in autumn, total DMI was greatest $(P<0.001)$ in autumn $(18.1$ $\mathrm{kg}$ of $\mathrm{DM} /$ cow per day), intermediate in summer (15.8 $\mathrm{kg}$ of $\mathrm{DM} / \mathrm{cow}$ per day), and least in spring (14.7 $\mathrm{kg}$ of $\mathrm{DM} /$ cow per day).

The LSR treatment achieved the greatest $(P<$ $0.001)$ total energy intake (17.1 UFL/d), whereas similar energy intake was achieved by both MSR (16.1 UFL/d) and HSR (15.9 UFL/d). Holstein-Friesian cows achieved a greater $(P<0.001)$ estimated energy intake (16.7 UFL/d) compared with JxHF cows (16.1 UFL/d). Season also had a significant effect on both total energy intake and energy balance due to the comparatively increased energy intake and balance of cows during summer (16.5 and $0.7 \mathrm{UFL} / \mathrm{d}$, respectively) and autumn (17.7 and $3.4 \mathrm{UFL} / \mathrm{d}$, respectively) compared with spring (14.9 and $-2.3 \mathrm{UFL} / \mathrm{d}$, respectively).

No significant effect was observed on the interactions of SR, BR, and S for grass and total DMI, and energy balance during the experimental period.

\section{Milk Production Efficiency}

The effect of SR and BR on milk production efficiencies are presented in Table 6 . The LSR group achieved the greatest total DMI per $100 \mathrm{~kg}$ of BW $(P<0.001$; $3.52 \mathrm{~kg}$ ) and also tended to produce additional MS per $100 \mathrm{~kg}$ of $\mathrm{BW}(P=0.09 ; 0.392 \mathrm{~kg})$, whereas similar performance was observed for both MSR (3.41 and $0.378 \mathrm{~kg}$, respectively) and HSR (3.35 and $0.379 \mathrm{~kg}$, respectively). Similarly, the energy (UFL) available for milk production after accounting for maintenance was greatest for LSR (11.9 UFL/d), while similar for MSR (11.0 UFL/d) and HSR (10.9 UFL/d).

Total DMI per $100 \mathrm{~kg}$ of BW and MS per $100 \mathrm{~kg}$ of BW were greater $(P<0.001)$ for JxHF cows $(3.55$ and $0.408 \mathrm{~kg} / 100 \mathrm{~kg}$, respectively) compared with HF cows (3.30 and $0.358 \mathrm{~kg} / 100 \mathrm{~kg}$, respectively). Additionally, JxHF cows required less (0.48 UFL; $P=0.03)$ energy to produce $1 \mathrm{~kg}$ of milk compared with HF (0.50 UFL). The total energy (UFL) and energy after accounting for maintenance available for MS production was greater for JxHF cows (115 and $168 \mathrm{~g}$ of MS/UFL intake, re-

Table 3. Effect of stocking rate ${ }^{1}$ and season ${ }^{2}$ on grass $\mathrm{OM}$ digestibility, CP, NDF, ADF, ash, and energy content during the intake measurement periods

\begin{tabular}{|c|c|c|c|c|c|c|c|}
\hline Stocking rate & Low & Medium & High & SEM & \multicolumn{3}{|c|}{ Significance $^{3}$} \\
\hline \multicolumn{8}{|c|}{ OM digestibility (\%) } \\
\hline Spring & 84.6 & 85.6 & 85.5 & \multirow{3}{*}{0.58} & \multirow{3}{*}{0.679} & \multirow{3}{*}{$<0.001$} & \multirow{3}{*}{0.935} \\
\hline Summer & 85.0 & 86.1 & 86.3 & & & & \\
\hline Autumn & 81.2 & 81.1 & 80.8 & & & & \\
\hline Summer & 174 & 198 & 168 & \multirow{2}{*}{5.4} & \multirow{2}{*}{0.059} & \multirow{2}{*}{0.004} & \multirow{2}{*}{0.246} \\
\hline Autumn & 184 & 196 & 166 & & & & \\
\hline \multicolumn{8}{|l|}{ NDF (g/kg) } \\
\hline Average & 377 & 376 & 377 & \multirow[t]{3}{*}{7.5} & \multirow[t]{3}{*}{0.992} & \multirow[t]{3}{*}{0.002} & \multirow[t]{3}{*}{0.627} \\
\hline Spring & 374 & 354 & 372 & & & & \\
\hline Summer & 360 & 375 & 357 & & & & \\
\hline Autumn & 230 & 234 & 220 & 5.4 & 0.280 & $<0.001$ & 0.984 \\
\hline \multicolumn{8}{|c|}{ Energy $\left(\mathrm{UFL}^{4} / \mathrm{kg}\right.$ of DM) } \\
\hline Average & 1.03 & 1.04 & 1.05 & \multirow[t]{4}{*}{0.007} & \multirow[t]{4}{*}{0.320} & \multirow[t]{4}{*}{$<0.001$} & \multirow[t]{4}{*}{0.949} \\
\hline Spring & 1.04 & 1.03 & 1.05 & & & & \\
\hline Summer & 1.05 & 1.06 & 1.08 & & & & \\
\hline Autumn & 1.00 & 1.01 & 1.02 & & & & \\
\hline
\end{tabular}

${ }^{1}$ Stocking rate $(\mathrm{BW} / \mathrm{ha})$ : low $=1,200 \mathrm{~kg}$ of $\mathrm{BW} / \mathrm{ha}$; medium $=1,400 \mathrm{~kg}$ of $\mathrm{BW} / \mathrm{ha}$; high =1,600 kg of $\mathrm{BW} / \mathrm{ha}$.

${ }^{2}$ Season: spring (March), summer (June), and autumn (September).

${ }^{3} \mathrm{SR}=$ stocking rate; $\mathrm{S}=$ season.

${ }^{4}$ UFL: unité fourragère lait (the net energy content of $1 \mathrm{~kg}$ of standard barley; that is, 1,700 kcal; Faverdin et al., 2011). 
spectively) relative to HF (108 and $162 \mathrm{~g}$ of MS/UFL intake, respectively).

No significant effect was observed on the interactions of SR, BR, and S for milk production efficiency during the experimental period.

\section{DISCUSSION}

Holmes et al. (2002) and McCarthy et al. (2011) previously suggested that cows per hectare is an increasingly misleading as a measure of SR in grazing systems. In the latter study, a meta-analysis review of the effect of SR on the productivity of grazing systems, the authors observed an interaction between cow BW and the milk production response to a change in SR. Consequently, alternative definitions of SR such as BW per hectare or BW per metric tonne of DM available (Holmes et al., 2002; Macdonald et al., 2008b) are considered to more accurately explain the relationship between SR and cow performance across a diversity of international grazing systems. As feed inputs were held constant, each SR and BR combination was uniquely defined in terms of BW per hectare within the integrated farm system framework of this experiment. The range of SR investigated within the present experiment $(1,200$ to $1,600 \mathrm{~kg}$ of $\mathrm{BW} / \mathrm{ha}$ and 75 to $95 \mathrm{~kg}$ of $\mathrm{BW} / \mathrm{t}$ of $\mathrm{DM})$ are within the biological range normally reported within the modern literature (Macdonald et al., 2008b; McCarthy et al., 2011).

\section{Daily Herbage Allowance, Grass, and Total DMI and Milk Production}

The mechanism by which differentials in whole-farm SR affect grazing characteristics, and cow intake and performance within the present experiment are similar to previous SR experiments (Macdonald et al., 2008a; McCarthy et al., 2013). Increasing SR was associated with a reduction in DHA, and consequently, reduced DMI and milk production per cow. Unlike a previous multi-year analysis (McCarthy et al., 2016), no differences in herbage quality were observed between SR within the measurement periods of the present experiment. The quantity of herbage allocated to MSR and HSR was reduced to 74 and $67 \%$, respectively, of that allocated to LSR. To counter the reduced DHA at higher SR, grazing severity was increased in both MSR and HSR to reduce the differential in DMI between SR treatments similar to previous studies (McCarthy et al., 2013). Consequently, LSR, MSR, and HSR grazed 77,96 , and $105 \%$, respectively, of the available herbage allocated (measured to $35 \mathrm{~mm}$ ), and by grazing to a 
COFFEY ET AL.

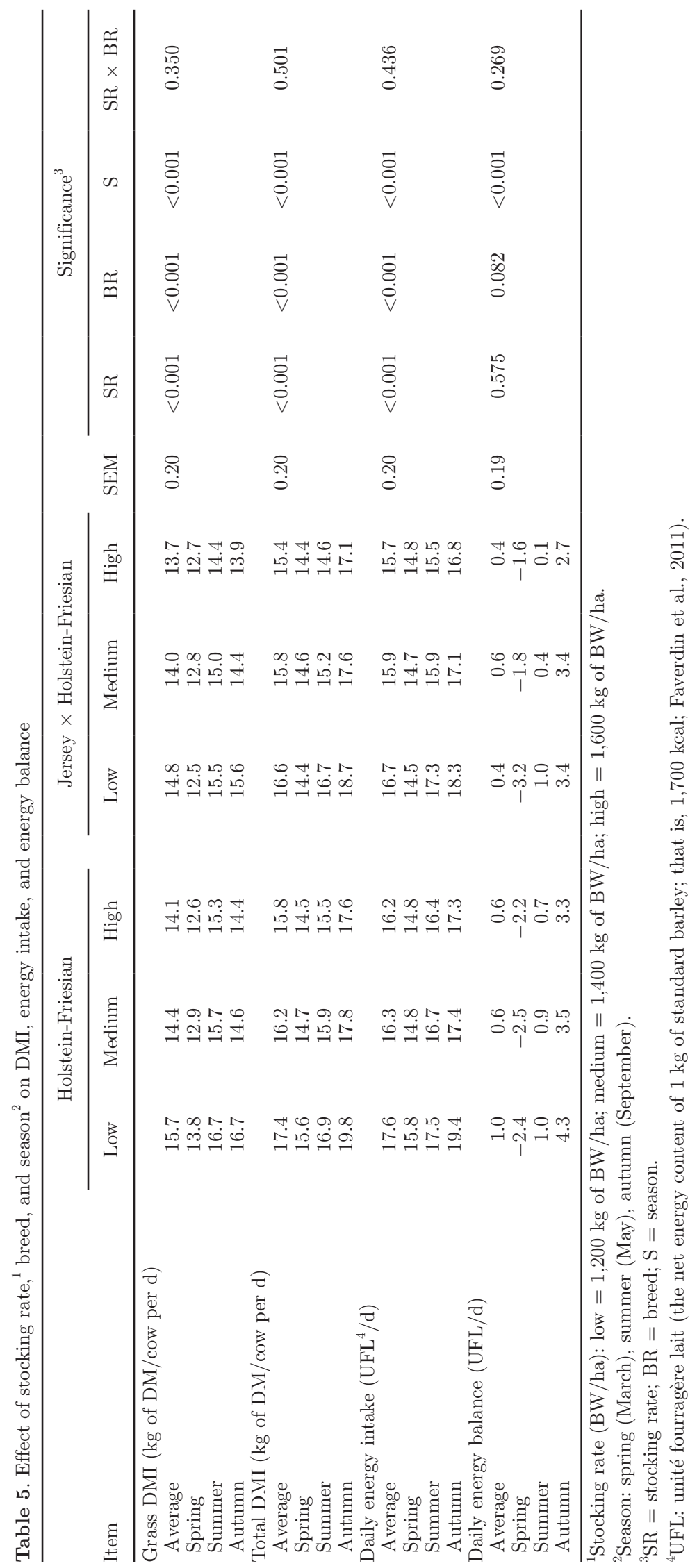




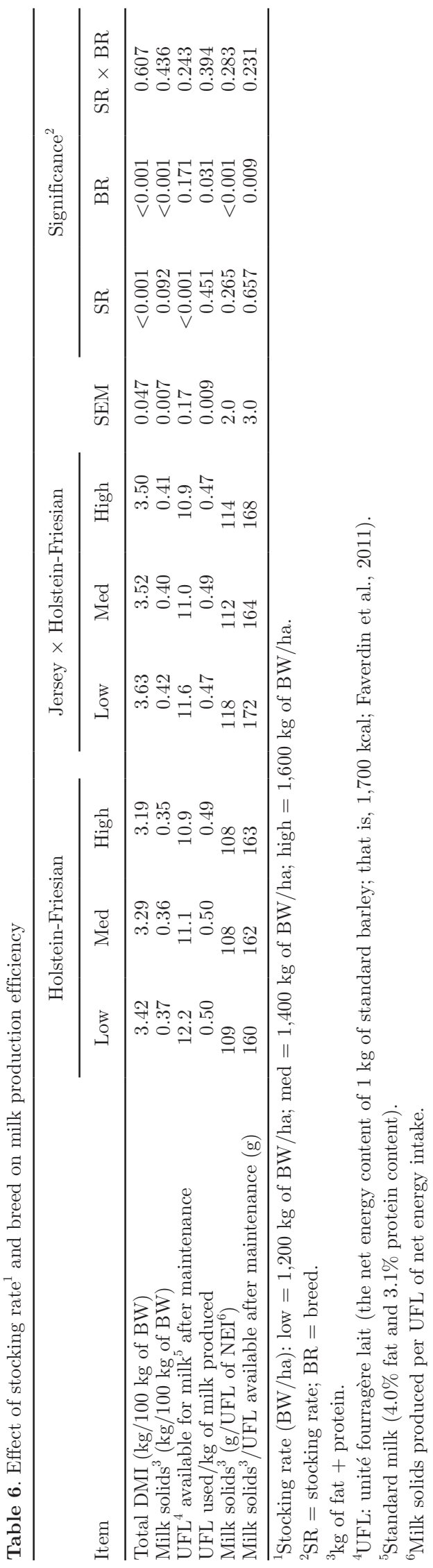

lower postCSH, MSR and HSR ultimately used 93 and $91 \%$ of the LSR grass DMI, respectively. Finally, the remaining differential in intake between $\mathrm{SR}$ was reflected in greater milk production per cow (milk, fat, protein, lactose, SCM, and MS yield) and increased BW in LSR compared with both MSR and HSR during the intake measurement periods. As SR increased by $400 \mathrm{~kg}$ of $\mathrm{BW} /$ ha $(33 \%)$ from LSR to HSR, a decrease occurred in daily milk production, equivalent to a 1.3 and $2.0 \%$ reduction in SCM and MS yield, respectively, coupled with a further $1.3 \%$ reduction in average BW per cow. Similar to McCarthy et al. (2013) and consistent with the differentials in total DMI between SR, the reduction in animal performance and total DMI occurs between LSR and MSR with few differences between MSR and HSR. The overall effects on MS observed are similar to those reported from a previous meta-analysis review of SR experiments (McCarthy et al., 2011; 2.0\% reduction in MS per $100 \mathrm{~kg}$ increase in BW/ha). Irrespective of BR effects, the comparably modest response in BW per cow and absence of BCS effects to SR change within the present analysis is consistent with the improved DMI capability and increased BCS of high EBI dairy cows reported previously within intensified grazing systems (Coleman et al., 2010; Moore et al., 2014).

The improved MS productivity of JxHF cows observed across all SR is consistent with previous experiments both within commercial and controlled research settings (Penasa et al., 2010; Prendiville et al., 2010b; Coffey et al., 2016). The JxHF cows achieved a higher MS yield $(2.3 \%$ or $0.04 \mathrm{~kg} /$ cow per d) driven by greater fat and protein composition from a reduced milk volume $(-6.4 \% ;-1.4 \mathrm{~kg} /$ cow per d) and with a reduced feed intake $(-3.6 \%$; $-0.6 \mathrm{~kg}$ of $\mathrm{DM} /$ cow per d). Mean $\mathrm{BW}$ of $\mathrm{HF}$ cows was $7.3 \%$ (36 kg) greater than JxHF cows in the present experiment and consistent with the 40,33 , and $50 \mathrm{~kg}$ differential, respectively, reported previously (Auldist et al., 2007; Heins et al., 2008; Prendiville et al., 2009).

Few studies have compared the feed intake of HF and JxHF crossbred cows on a predominantly grass diet. Prendiville et al. (2010a) reported no difference in intake between HF and JxHF cows (16.9 and $16.2 \mathrm{~kg}$ of $\mathrm{DM} /$ cow per d, respectively) within Irish grazing systems at similar SR to the present experiment. Similarly, both Gonzalez-Verdugo et al. (2005) and Vance et al. (2012) have also reported similar DMI for HF and JxHF genotypes at grazing. In comparison with the similarity in DMI per cow between HF and JxHF within previous studies, the reduced DMI (3.6\% or $0.6 \mathrm{~kg}$ of DM/ cow/d) of JxHF cows in the present experiment is an artifact of the uniquely similar BW per hectare design, which more accurately reflects the DMI capabilities of these BR groups within comparable system scenarios. 


\section{Milk Production Efficiency}

The measures of gross FCE used in the present experiment do not distinguish energy use between the alternative components for production, body maintenance, growth, gestation, or restoration of body reserves. As no significant BR effect on BCS was evident within this experiment, potential differences in body reserve mobilization and restoration between BR groups are considered negligible. In a separate analysis undertaken on a subset of data from the present experiment, Leane (2016) observed no differences in BCS change or metabolic indicators of nutritional status and reproductive performance between BR groups. Additionally, although not reported in the literature, no difference was observed in health between BR groups in the present experiment. The overall level of total DMI/100 kg of $\mathrm{BW}, \mathrm{MS} / 100 \mathrm{~kg}$ of $\mathrm{BW}$, and MS/gram of DMI within the experiment $(3.42 \mathrm{~kg}, 0.383 \mathrm{~kg}$, and $111 \mathrm{~g}$, respectively) compare favorably with previous comparable grazing studies (Mackle et al., 1996; Prendiville et al., 2009; Beecher et al., 2014) and is indicative of highly efficient intensive grazing systems.

The decline in total DMI/100 kg of BW at higher SR within the present experiment is consistent with previous findings (Macdonald et al., 2008a; McCarthy et al., 2014) due to the reduced DHA and total DMI of higher SR treatments (McEvoy et al., 2010; McCarthy et al., 2011). As animal maintenance requirements are unaffected by SR, DMI availability for milk production is reduced within increasingly feed restricted high SR systems where the amount and quality of feed eaten most often restricts milk yield (Kolver and Muller, 1998). Total DMI/cow per day was reduced by $8.2 \%$, whereas total DMI/100 kg of BW decreased by $4.8 \%$ as SR increased from LSR to HSR. Despite the reduced total DMI/100 kg of BW of the higher SR treatments, MS production both per $100 \mathrm{~kg}$ of $\mathrm{BW}$ and per UFL of net energy intake were similar between SR groups, thereby reflecting the overall adequacy of feed supply within the higher SR in the present experiment.

Within intensive pasture-based systems, dairy cows must be capable of achieving large intakes of high quality grass per unit of BW and efficiently converting the feed to high value MS (Buckley et al., 2005). The similarity in DMI and milk production between HF and smaller JxHF cows in previous studies has been attributed to several factors including differences in cow BW and grazing behavior (Prendiville et al., 2010a; Vance et al., 2012), gastrointestinal tract weight (Beecher et al., 2014), DMI capacity (Goddard and Grainger, 2004), and NDF digestibility (Aikman et al., 2008). The increased production efficiency of JxHF cows at similar BW/ha in the current analysis suggests that factors other than individual cow BW contribute to the improved efficiency within intensive grazing systems. At similar BW per hectare, JxHF cows achieved $8 \%$ greater total $\mathrm{DMI} / 100 \mathrm{~kg}$ of $\mathrm{BW}, 14 \%$ greater MS output per $100 \mathrm{~kg}$ of $\mathrm{BW}, 7 \%$ greater MS output per UFL intake, and $5 \%$ greater MS production per UFL intake after accounting for maintenance and gestation compared with HF cows. Similarly, Prendiville et al. (2009) and Beecher et al. (2014) reported a 6.6 and $3.6 \%$ increase in DMI per $100 \mathrm{~kg}$ of BW, respectively, when comparing JxHF and HF cows in previous grazing studies. The observed differences in feed intake capacity at grazing between the breeds result in $\mathrm{HF}$ cows having lower FCE than their JxHF counterparts, as a greater proportion of their energy intake will be allocated to maintenance requirements (Grainger and Goddard, 2007). This greater dilution of maintenance requirements by JxHF cow ultimately results in increased MS production per kilogram of DMI and per unit of BW. Milk solids as a percentage of BW and MS relative to total DMI were similar to those reported previously by both Beecher et al. (2014; 13 and 3.1\%, respectively) and Prendiville et al. (2009; 16 and 9.2\%, respectively). Finally, and despite similar BW per hectare, the JxHF cows exhibited superior FCE, manifested in a $4 \%$ reduction in energy requirements to produce 1 $\mathrm{kg}$ of milk and a $7 \%$ reduction in energy requirements to produce $1 \mathrm{~kg}$ of MS relative to $\mathrm{HF}$ counterparts. Similarly, Prendiville et al. (2009) observed that JxHF cows require $11 \%$ (1.6 UFL) less energy than HF cows to produce $1 \mathrm{~kg}$ of MS at similar overall SR.

The overall SR coupled with reduced feed supplementation levels evaluated within the present experiment are relatively unique in comparison with either commercial practice (Ramsbottom et al., 2015) or previous SR experiments (McCarthy et al., 2011) and is indicative of the potential for increased milk and pasture productivity attainable by increasing SR and pasture utilization. Within such systems, the results of the current analysis indicate that the selection of high genetic potential JxHF cows of reduced BW, with improved FCE can significantly enhance the overall efficiency of milk production. The present experiment adds further credence to a wide body of international research that points to the superior compatibility of JxHF cows within grazing systems (Lopez-Villalobos et al., 2000; Prendiville et al., 2010a; Coffey et al., 2016).

\section{CONCLUSIONS}

Within intensive pasture-based systems, milk production and BW per cow decreased significantly as SR increased because of a decrease in herbage availability and DMI per cow. Regardless of SR, there is a similar 
energy requirement for maintenance, and therefore, at higher SR, less energy is available for milk production. The smaller size and associated lower intake of JxHF cows appear to be compensated for by lower maintenance energy requirements, and consequently, MS yield production per cow and MS production as a percentage of BW were greater for JxHF than HF during the intake measurement periods. Although the opportunity to improve efficiency is limited within ruminant production systems, this experiment has demonstrated the ability of the JxHF cow to produce more milk from lower feed inputs, offering the potential to improve overall sustainability and profitability of dairy production systems.

\section{ACKNOWLEDGMENTS}

The authors thank the staff of Curtin's Research Farm (Animal \& Grassland Research and Innovation Center, Teagasc Moorepark, Ireland) for their cooperation and the care and management of the experimental cows. The authors acknowledge the financial support of Dairy Research Ireland.

\section{REFERENCES}

Aikman, P. C., C. K. Reynolds, and D. E. Beever. 2008. Diet digestibility, rate of passage, and eating and rumination behavior of Jersey and Holstein cows. J. Dairy Sci. 91:1103-1114.

Auldist, M. J., M. F. S. Pyman, C. Grainger, and K. L. Macmillan. 2007. Comparative reproductive performance and early lactation productivity of Jersey $\times$ Holstein cows in predominantly Holstein herds in a pasture-based dairying system. J. Dairy Sci. 90:48564862.

Beecher, M., F. Buckley, S. M. Waters, T. M. Boland, D. EnriquezHidalgo, M. H. Deighton, M. O'Donovan, and E. Lewis. 2014. Gastrointestinal tract size, total-tract digestibility, and rumen microflora in different dairy cow genotypes. J. Dairy Sci. 97:3906-3917.

Berry, D. P., and J. J. Crowley. 2013. Cell Biology Symposium: Genetics of feed efficiency in dairy and beef cattle. J. Anim. Sci. 91:1594-1613.

Buckley, F., C. Holmes, and G. Keane. 2005. Genetic characteristics required in dairy and beef cattle for temperate grazing systems. Pages 61-78 in XX International Grassland Congress, Cork Satellite Meeting. Wageningen Academic Publishers, Wageningen, the Netherlands.

Coffey, E. L., B. Horan, R. D. Evans, and D. P. Berry. 2016. Milk production and fertility performance of Holstein, Friesian, and Jersey purebred cows and their respective crosses in seasonal-calving commercial farms. J. Dairy Sci. 99:5681-5689.

Coleman, J., D. P. Berry, K. M. Pierce, A. Brennan, and B. Horan. 2010. Dry matter intake and feed efficiency profiles of 3 genotypes of Holstein-Friesian within pasture-based systems of milk production. J. Dairy Sci. 93:4318-4331.

Delaby, L., and J. L. Peyraud. 1998. Effect of a simultaneous reduction in nitrogen fertilization and stocking rate on the performance of dairy cows and pasture utilization. Ann. Zootech. 47:17-39.

Dillon, P., and G. Stakelum. 1989. Herbage and dosed alkanes as a grass measurement technique for dairy cows. Irish J. Agric. Sci. Res. 28:104.

Dillon, P. A. T., T. Hennessy, L. Shalloo, F. Thorne, and B. Horan. 2008. Future outlook for the Irish dairy industry: A study of inter- national competitiveness, influence of international trade reform and requirement for change. Int. J. Dairy Technol. 61:16-29.

Dong, L. F., T. Yan, C. P. Ferris, and D. A. McDowell. 2015. Comparison of maintenance energy requirement and energetic efficiency between lactating Holstein-Friesian and other groups of dairy cows. J. Dairy Sci. 98:1136-1144.

Edmonson, A. J., I. J. Lean, L. D. Weaver, T. Farver, and G. Webster. 1989. A body condition scoring chart for Holstein dairy cows. J. Dairy Sci. 72:68-78.

Faverdin, P., C. Baratte, R. Delagarde, and J. L. Peyraud. 2011. GrazeIn: A model of herbage intake and milk production for grazing dairy cows. 1. Prediction of intake capacity, voluntary intake and milk production during lactation. Grass Forage Sci. 66:29-44.

Finneran, E., P. Crosson, P. O'Kiely, L. Shalloo, D. Forristal, and M. Wallace. 2010. Simulation modelling of the cost of producing and utilising feeds for ruminants on Irish farms. J. Farm Manag. 14:95-116.

Goddard, M. E., and C. Grainger. 2004. A review of the effects of dairy breed on feed conversion efficiency-An opportunity lost? Pages 77-80 in Proc. 25th Biennial Conf Aust. Soc. Anim. Prod. University of Melbourne, Victoria, Australia. CSIRO, Victoria, Australia.

Gonzalez-Verdugo, H., J. C. Magofke, and C. Mella. 2005. Productivity, intake and biological efficiency in New Zealand Friesian and F-1 (Jersey-New Zealand Friesian) cows calved during late winter in the X-th Region, Chile. Arch. Med. Vet. 37:37-47.

Grainger, C., and M. E. Goddard. 2007. A review of the effects of dairy breed on feed conversion efficiency. Pages 84-92 in 3rd Dairy Sci. Symp. Meeting the Challenges of Pasture-Based Dairying, University of Melbourne, Victoria, Australia. CSIRO, Victoria, Australia.

Heins, B. J., L. B. Hansen, A. J. Seykora, A. R. Hazel, D. G. Johnson, and J. G. Linn. 2008. Crossbreds of Jersey $\times$ Holstein compared with pure Holsteins for body weight, body condition score, dry matter intake, and feed efficiency during the first one hundred fifty days of first lactation. J. Dairy Sci. 91:3716-3722.

Holmes, C. W., G. F. Wilson, D. D. S. Mackenzie, D. S. Flux, I. M. Brookes, and A. W. F. Davey. 2002. Feeding the herd. Pages 33-89 in Milk Production from Pasture, Butterworths, Wellington, New Zealand.

Horan, B., P. Faverdin, L. Delaby, M. Rath, and P. Dillon. 2006. The effect of strain of Holstein-Friesian dairy cow and pasture-based system on grass intake and milk production. Anim. Sci. 82:435444

ICBF. 2015. Irish Cattle Breeding Federation. Accessed Dec. 10, 2015. http://www.icbf.com.

Kennedy, E., M. McEvoy, J. P. Murphy, and M. O'Donovan. 2009. Effect of restricted access time to pasture on dairy cow milk production, grazing behavior, and dry matter intake. J. Dairy Sci. 92:168-176.

Kolver, E. S., and L. D. Muller. 1998. Performance and nutrient intake of high producing Holstein cows consuming pasture or a total mixed ration. J. Dairy Sci. 81:1403-1411.

Leane, S. 2016. Nutritional effects on reproduction in pasture based milk production systems. PhD thesis. School of Agriculture and Food, National University of Ireland, University College Dublin.

Lopez-Villalobos, N., D. J. Garrick, C. W. Holmes, H. T. Blair, and R. J. Spelman. 2000. Effects of selection and crossbreeding strategies on industry profit in the New Zealand dairy industry. J. Dairy Sci. $83: 164-172$

Macdonald, K. A., J. W. Penno, J. A. S. Lancaster, and J. R. Roche. 2008a. Effect of stocking rate on pasture production, milk production, and reproduction of dairy cows in pasture-based systems. J. Dairy Sci. 91:2151-2163.

Macdonald, K. A., G. A. Verkerk, B. S. Thorrold, J. E. Pryce, J. W. Penno, L. R. McNaughton, L. J. Burton, J. A. S. Lancaster, J. H. Williamson, and C. W. Holmes. 2008b. A comparison of three strains of Holstein-Friesian grazed on pasture and managed under different feed allowances. J. Dairy Sci. 91:1693-1707.

Mackle, T. R., C. R. Parr, G. K. Stakelum, A. M. Bryant, and K. L. MacMillan. 1996. Feed conversion efficiency, daily pasture in- 
take, and milk production of primiparous Friesian and Jersey cows calved at two different liveweights. N. Z. J. Agric. Res. 39:357-370.

Mayes, R. W., C. S. Lamb, and P. M. Colgrove. 1986. The use of dosed and herbage n-alkanes as markers for the determination of herbage intake. J. Agric. Sci. 107:161-170.

McCarthy, B., L. Delaby, K. M. Pierce, A. Brennan, and B. Horan. 2013. The effect of stocking rate and calving date on milk production of Holstein-Friesian dairy cows. Livest. Sci. 153:123-134.

McCarthy, B., L. Delaby, K. M. Pierce, F. Journot, and B. Horan. 2011. Meta-analysis of the impact of stocking rate on the productivity of pasture-based milk production systems. Animal 5:784-794.

McCarthy, B., L. Delaby, K. M. Pierce, J. McCarthy, C. Fleming, A. Brennan, and B. Horan. 2016. The multi-year cumulative effects of alternative stocking rate and grazing management practices on pasture productivity and utilization efficiency. J. Dairy Sci. 99:3784-3797.

McCarthy, B., K. M. Pierce, L. Delaby, A. Brennan, and B. Horan. 2012. The effect of stocking rate and calving date on reproductive performance, body state, and metabolic and health parameters of Holstein-Friesian dairy cows. J. Dairy Sci. 95:1337-1348.

McCarthy, J., L. Delaby, D. Hennessy, B. McCarthy, W. Ryan, K. M. Pierce, A. Brennan, and B. Horan. 2015. The effect of stocking rate on soil solution nitrate concentrations beneath a free-draining dairy production system in Ireland. J. Dairy Sci. 98:4211-4224.

McCarthy, J., B. McCarthy, B. Horan, K. M. Pierce, N. Galvin, A. Brennan, and L. Delaby. 2014. Effect of stocking rate and calving date on dry matter intake, milk production, body weight, and body condition score in spring-calving, grass-fed dairy cows. J. Dairy Sci. 97:1693-1706.

McEvoy, M., L. Delaby, J. P. Murphy, T. M. Boland, and M. O'Donovan. 2010. Effect of herbage mass and allowance on sward characteristics, milk production, intake and rumen volatile fatty acid concentration. Grass Forage Sci. 65:335-347.

Moore, S. G., T. Fair, P. Lonergan, and S. T. Butler. 2014. Genetic merit for fertility traits in Holstein cows: IV. Transition period, uterine health, and resumption of cyclicity. J. Dairy Sci. 97:27402752 .

Penasa, M., N. Lopez-Villalobos, R. D. Evans, A. R. Cromie, R. Da Zotto, and M. Cassandro. 2010. Crossbreeding effects on milk yield traits and calving interval in spring-calving dairy cows. J. Anim. Breed. Genet. 127:300-307.
Prendiville, R., E. Lewis, K. M. Pierce, and F. Buckley. 2010a. Comparative grazing behavior of lactating Holstein-Friesian, Jersey, and Jersey $\times$ Holstein-Friesian dairy cows and its association with intake capacity and production efficiency. J. Dairy Sci. 93:764-774.

Prendiville, R., K. M. Pierce, and F. Buckley. 2009. An evaluation of production efficiencies among lactating Holstein-Friesian, Jersey, and Jersey $\times$ Holstein-Friesian cows at pasture. J. Dairy Sci. 92:6176-6185.

Prendiville, R., K. M. Pierce, L. Delaby, and F. Buckley. 2010b. Animal performance and production efficiencies of Holstein-Friesian, Jersey and Jersey x Holstein-Friesian cows throughout lactation. Livest. Sci. 138:25-33.

Pryce, J. E., O. Gonzalez-Recio, G. Nieuwhof, W. J. Wales, M. P. Coffey, B. J. Hayes, and M. E. Goddard. 2015. Hot topic: Definition and implementation of a breeding value for feed efficiency in dairy cows. J. Dairy Sci. 98:7340-7350.

Ramsbottom, G., B. Horan, D. P. Berry, and J. R. Roche. 2015. Factors associated with the financial performance of spring-calving, pasture-based dairy farms. J. Dairy Sci. 98:3526-3540.

SAS Institute Inc. 2010. User's Guide: Statistics. Version 9.3. SAS Institute Inc., Cary, NC.

Shalloo, L., P. Dillon, M. Rath, and M. Wallace. 2004. Description and validation of the Moorepark dairy system model. J. Dairy Sci. $87: 1945-1959$.

Stakelum, G., and J. Connolly. 1987. Effect of body size and milk yield on intake of fresh herbage by lactating dairy cows indoors. Isr. J. Agric. Res. 26:9-22.

Tozer, P. R., F. Bargo, and L. D. Muller. 2004. The effect of pasture allowance and supplementation on feed efficiency and profitability of dairy systems. J. Dairy Sci. 87:2902-2911.

Tyrrell, H. F., and J. T. Reid. 1965. Prediction of the energy value of cow's milk. J. Dairy Sci. 48:1215-1223.

Vance, E. R., C. P. Ferris, C. T. Elliott, S. A. McGettrick, and D. J. Kilpatrick. 2012. Food intake, milk production, and tissue changes of Holstein-Friesian and Jersey $\times$ Holstein-Friesian dairy cows within a medium-input grazing system and a high-input total confinement system. J. Dairy Sci. 95:1527-1544.

Veerkamp, R. F. 1998. Selection for economic efficiency of dairy cattle using information on live weight and feed intake: A review. J. Dairy Sci. 81:1109-1119. 